\title{
Exogenous nitric oxide (NO) ameliorates salinity-induced oxidative stress in tomato (Solanum lycopersicum) plants
}

\author{
J. Manai ${ }^{*}$, T. Kalai ${ }^{1}$, H. Gouia ${ }^{1}$, F. J. Corpas ${ }^{2}$ \\ ${ }^{1}$ Unité de Recherche Nutrition et Métabolisme Azotés et Protéines de Stress 99/UR/C 09-20, Département of Biological Sciences, \\ Faculté des Sciences de Tunis, Université Tunis EL Manar 1060, Tunisia. ${ }^{2}$ Group of Antioxidants, Free Radicals and Nitric \\ Oxide in Biotechnology, Food and Agriculture, Department of Biochemistry, Cell and Molecular Biology of Plants, Estación \\ Experimental del Zaidin, CSIC, 18080 Granada,SSain. *Correspondingauthor: jamel_ma@yahoo.fr
}

\begin{abstract}
Nitric oxide (NO) is involved in numerous physiological and stress responses in higher plants. Tomato is one of the most important vegetable crops in the world and previously it has been reported that salinity induced an oxidative stress affecting its redox and $\mathrm{NO}$ homeostasis. Using tomato plant exposed to $120 \mathrm{mM} \mathrm{NaCl}$, it was studied whether the exogenous application of NO could ameliorate the negative effects provoked by salinity. Thus, nitric oxide provoked a significantly increase in the main antioxidative enzymes including superoxide dismutase (SOD), ascorbate peroxidase (APX), glutathione reductase (GR) and peroxidase (POD) activities, and also a raise of some enzymes involved in nitrogen metabolism including nitrate reductase (NR) and nitrite reductase (NiR) activities. Moreover, NO-treated plants showed a higher content in both proline and ascorbate but lower content of $\mathrm{H}_{2} \mathrm{O}_{2}$. These data indicate that the exogenous $\mathrm{NO}$ application is useful to mitigate the salinity-induced oxidative stress in tomato plants.
\end{abstract}

Keywords: Salt stress, tomato, nitric oxide, antioxidant system, nitrogen metabolism

\section{Introduction}

Salinity is an environmental stress which is constantly expanding around the world. In plants, salinity can induce damages in proteins, lipids and nucleic acids, and alterations in photosynthesis and respiration which affect plant growth and development. To overcome potential damages, higher plants have multiple protective mechanisms against salt stress including ion homeostasis, osmolyte biosynthesis, reactive oxygen species (ROS) scavenging, water transport and transducers of long-distance response coordination (Tuteja, 2007). In many cases, salinity stress contains an oxidative stress component due to the uncontrolled generation of ROS which provokes damage to macromolecules or even damage to the antioxidative system (Manaa et al., 2013). The antioxidative enzymatic system includes the enzymes superoxide dismutases (SOD), and catalase (CAT) and peroxidases which are involved in the detoxification of superoxide radical $\left(\mathrm{O}_{2}{ }^{-}\right)$, and hydrogen peroxide $\left(\mathrm{H}_{2} \mathrm{O}_{2}\right)$, respectively, thereby preventing the formation of hydroxyl radicals ('OH) (Gill and Tuteja, 2010). Ascorbate peroxidase (APX), monodehydroasecorbate 
reductase (MDAR) and glutathione reductase (GR), as well as glutathione (GSH) and ascorbate, are also important components of the ascorbate-glutathione cycle responsible for the removal of $\mathrm{H}_{2} \mathrm{O}_{2}$ in different cellular compartments (Foyer and Noctor, 2005). All these antioxidant components must work coordinately to provide a successful response against a specific stress.

Nitric oxide (NO) is one of the most studied bioactive molecules, due to its involvement in a wide spectrum of physiological processes from bacteria to human. In higher plants, NO has an important function in plant growth and development, in processes including seed germination, primary and lateral root growth, flowering, pollen tube growth regulation, fruit ripening, senescence, defence response and abiotic stresses, and NO is also a key signalling molecule in different intracellular processes (Nasibi and Kalantari, 2009; Corpas et al., 2011). The participation of NO in the mechanism of response to salinity stress has been also reported, although the information available can sometimes be contradictory, depending of the plant species and the severity of the salinity treatment (Zhao et al., 2004; Begara-Morales et al., 2014). Previously, we have demonstrated that salinity drastically affects redox and NO homeostasis in tomato roots (Manai et al., 2014). Based in these data, the goal of the present work was to study whether the exogenous NO application throughout tomato roots could modulate the antioxidant defense in growing tomato plants under $\mathrm{NaCl}$ stress and evaluate also if this response could alleviate $\mathrm{NaCl}$ toxicity.

\section{Materials and Methods}

\subsection{Plant material and growth condition}

Tomato (Solanum lycopersicum, Mill. 'Chibli F1') seeds were surface sterilized with $20 \%$ (v/v) calcium hypochlorite solution for $20 \mathrm{~min}$, and then were washed with distilled water, and germinated on moist filter papers at $25{ }^{\circ} \mathrm{C}$ in the dark. Healthy and vigorous seedlings were selected and grown in aerated optimum-nutrient solutions containing $2 \mathrm{mM} \mathrm{KNO}_{3}$, $1 \mathrm{mM} \mathrm{Ca}\left(\mathrm{NO}_{3}\right)_{2}, 2 \mathrm{mM} \mathrm{KH} \mathrm{PO}_{4}, 0.5 \mathrm{mM} \mathrm{MgSO}$, $32.9 \mathrm{mM}$ Fe-K-EDTA and the micronutrients $30 \mu \mathrm{M}$ $\mathrm{H}_{3} \mathrm{BO}_{4}, 5 \mu \mathrm{M} \mathrm{MnSO}_{4}, 1 \mu \mathrm{M} \mathrm{CuSO}_{4}, 1 \mu \mathrm{M} \mathrm{ZnSO}_{4}$ and $1 \mu \mathrm{M}\left(\mathrm{NH}_{4}\right)_{6} \mathrm{Mo}_{7} \mathrm{O}_{24}$ for 8 days. Then, tomato plants were subjected for additional $8 \mathrm{~d}$ to stress with $120 \mathrm{mM}$ $\mathrm{NaCl}$ either with or without $100 \mu \mathrm{M}$ or $300 \mu \mathrm{M}$ sodium nitroprusside (SNP) as NO donor. The growth chamber conditions were: $26{ }^{\circ} \mathrm{C} / 20{ }^{\circ} \mathrm{C}$ (day/night), $70 \%-90 \%$ relative humidity (day/night), a $16 \mathrm{~h}$ photoperiod, and a light intensity of $150 \mu \mathrm{mol} \mathrm{m} \mathrm{m}^{-2} \mathrm{~s}^{-1}$. Samples (leaves and roots) were harvested $6 \mathrm{~h}$ after the beginning of the light phase, immediately frozen in liquid nitrogen and stored at $-80{ }^{\circ} \mathrm{C}$ until further analysis.

\subsection{Crude extracts}

Leaves and roots from control and $\mathrm{NaCl}$-treated tomato plants were ground in liquid nitrogen using a mortar and pestle. The resulting powder was added to $1 / 3(\mathrm{w} / \mathrm{v})$ extraction medium of $50 \mathrm{mM}$ potassium phosphate buffer, $\mathrm{pH}$ 7.0, containing $1 \mathrm{mM}$ EDTA and 5\% (v/v) polyvinylpoly-pyrrolidone (PVPP). For the ascorbate peroxidase (APX) assay, the extraction medium was also added with $5 \mathrm{mM}$ ascorbate. The crude extracts were centrifuged at $14,000 \mathrm{~g}$ for $30 \mathrm{~min}$ at $4{ }^{\circ} \mathrm{C}$, and the supernatants were used for assays. For nitrate and nitrite reductase activities the extraction buffer was quite different. Thus, the resulting powder was added to $1 / 8(\mathrm{w} / \mathrm{v})$ extraction medium of $100 \mathrm{mM}$ potassium phosphate buffer, pH 7.4 containing $1 \mathrm{mM}$ EDTA, 7.5 $\mathrm{mM}$ cysteine and $2.5 \%(\mathrm{w} / \mathrm{v})$ casein. The homogenate was centrifuged at $30,000 \mathrm{~g}$ for $15 \mathrm{~min}$ at $4{ }^{\circ} \mathrm{C}$.

Protein content was determined spectrophotometrically at $595 \mathrm{~nm}$ as described by Bradford (1976) using bovine serum albumin (BSA) as standard.

\subsection{Enzymatic activity assays}

Superoxide dismutase (SOD, EC 1.15.1.1) activity was measured spectrophotometrically at $560 \mathrm{~nm}$ according to Beyer and Fridovich (1987). Catalase (EC 1.11.1.6) was 
determined by measuring the disappearance of $\mathrm{H}_{2} \mathrm{O}_{2}$, as described by Aebi (1984). Ascorbate peroxidase (APX, EC 1.11.1.11) activity was determined by monitoring the initial ascorbate oxidation by $\mathrm{H}_{2} \mathrm{O}_{2}$ at $290 \mathrm{~nm}$ (Chen and Asada(1989). Glutathion reductase (GR, EC 1.6.4.2) activity was determined by following the NADPH oxidation at $340 \mathrm{~nm}$ as described by Rao et al. (1996). Peroxidase (POD, EC 1.11.1.7) activity was assayed using guaiacol as a substrate according to Nickel and Cunningham (1969) which is based in the increase in absorbance at $470 \mathrm{~nm}$ due to the guaiacol oxidation. The reaction mixture contained $25 \mathrm{mM}$ phosphate buffer ( $\mathrm{pH} 7.0$ ), $0.05 \%(\mathrm{v} / \mathrm{v})$ guaiacol, $1.0 \mathrm{mM} \mathrm{H}_{2} \mathrm{O}_{2}$ and $0.1 \mathrm{ml}$ plant sample. The activity was expressed as $\mathrm{U} \mathrm{mg}^{-1}$ protein.

Nitrate reductase (NR, EC 1.7.99.4) activity was determined according to the method of Robin (1979). Briefly, samples were incubated in a reaction mixture of $100 \mathrm{mM}$ potassium phosphate buffer $(\mathrm{pH}$ 7.4) containing $10 \mathrm{mM}$ EDTA, $0.15 \mathrm{mM}$ NADH and $0.1 \mathrm{M}$ $\mathrm{KNO}_{3}$ for $30 \mathrm{~min}$ at $30{ }^{\circ} \mathrm{C}$. The reaction was stopped by adding $100 \mu \mathrm{L}$ of $1 \mathrm{M}$ zinc acetate. Absorbance of the supernatant was determined at $540 \mathrm{~nm}$ after diazotation of nitrite ions with $5.8 \mathrm{mM}$ sulfanilamide and $0.8 \mathrm{mM}$ $\mathrm{N}$-(1-naphthyl)-ethylene-diamine-dihydrochloride (NNEDD). Nitrite reductase (NiR, EC 1.7.2.1) activity was measured according to Losada and Paneque (1971) based in the nitrite reduction at $540 \mathrm{~nm}$. NiR activity was expressed as $\mu \mathrm{mol} \mathrm{NO}{ }_{2}^{-} \cdot \mathrm{h}^{-1} \cdot \mathrm{g}^{-1} \mathrm{FW}$ ).

\subsection{Determination of ascorbate (ASC) content}

ASC content was determined according to Hodges et al. (1996). Samples $(0.3 \mathrm{~g})$ were homogenized with $5 \% \mathrm{~m}$-phosphoric acid $(2 \mathrm{ml})$. The homogenate was centrifuged at $12,000 \mathrm{~g}$ for $20 \mathrm{~min}$. Then, the supernatant $(100 \mu \mathrm{l})$ was mixed with $500 \mu \mathrm{KH}_{2} \mathrm{PO}_{4}$ buffer $(150$ $\mathrm{mM}, \mathrm{pH}$ 7.4) containing $5 \mathrm{~m} \mathrm{M}$ EDTA, and color was developed by adding $400 \mu \mathrm{l} 10 \%((\mathrm{w} / \mathrm{v})$ trichloroacetic acid, $400 \mu 1$ 44\% (v/v) o-phosphoric acid, $400 \mu \mathrm{l}$ o-dipyridyl in $70 \%$ (v/v) ethanol and $200 \mu 1$ of $0.03 \%$ $(\mathrm{w} / \mathrm{v}) \mathrm{FeCl}_{3}$. The reaction mixtures were incubated at 40 ${ }^{\circ} \mathrm{C}$ for $1 \mathrm{~h}$ and the absorbance was measured at $525 \mathrm{~nm}$.

\subsection{Determination of proline content}

Free proline content was determined according to Bates et al. (1973). Samples (0.5 g) were homogenized with $3 \%$ sulphosalycylic acid. Homogenates were filtered through filter paper. After addition of $2 \mathrm{ml}$ of acidic ninhydrin reagent $(2.5 \mathrm{~g}$ ninhydrin/100 $\mathrm{ml}$ of solution containing glacial acetic acid, distilled water and orthophosphoric acid $85 \%$ at a ratio of $6: 3: 1)$ and $1 \mathrm{ml}$ glacial acetic acid, resulting mixture was incubated at $100{ }^{\circ} \mathrm{C}$ for $1 \mathrm{~h}$ in water bath. Reaction was then stopped using ice bath. The mixture was extracted with toluene, and the absorbance was measured at $520 \mathrm{~nm}$.

\subsection{Determination of $\mathrm{H}_{2} \mathrm{O}_{2}$ content, and lipid peroxidation}

$\mathrm{H}_{2} \mathrm{O}_{2}$ content was determined according to Wolff (1994). The assay is based on ferrous ion oxidation in the presence of the ferric ion indicator xylenol orange. Lipid peroxidation was measured in terms of malondialdehyde (MDA) content according to the method described by Cavalcanti et al. (2004). Samples $(0.5 \mathrm{~g})$ were homogenized with a mortar and pestle in $4 \mathrm{ml}$ of $1 \%(\mathrm{w} / \mathrm{v})$ trichloroacetic acid (TCA) at $4{ }^{\circ} \mathrm{C}$. Homogenates were centrifuged at $12,000 \mathrm{~g}$ for $20 \mathrm{~min}$. Supernatant $(1 \mathrm{ml})$ was added to a reaction mixture $(3 \mathrm{ml})$ containing $20 \%(\mathrm{w} / \mathrm{v})$ TCA and $0.5 \%(\mathrm{w} / \mathrm{v})$ thiobarbituric acid (TBA). The mixture was incubated at $95{ }^{\circ} \mathrm{C}$ for $30 \mathrm{~min}$ and the reaction was stopped by quickly placing in an ice bath. The absorbance of the fraction was measured at 440 , 532 and $600 \mathrm{~nm}$.

\subsection{Native polyacrylamide gel electrophoresis and isozyme staining}

Native polyacrylamide gel electrophoresis (PAGE) was performed using a BioRad mini-gel system at $4{ }^{\circ} \mathrm{C}$, $120 \mathrm{~V}$ for $90 \mathrm{~min}$. For SOD, the tomato samples were subjected to native PAGE with $10 \%$ resolving gel and $4 \%$ stacking gels. SOD activity was assayed using the method of Beauchamp and Fridovich (1971). 


\subsection{Statistical analysis}

Pair-wise analyses of variance (ANOVA) were used to detect differences among treatments, $\mathrm{p}$-values $<0.05$ were considered statiscally significant.

\section{Results}

\subsection{Growth parameters and photosynthetic pigment} contents

Table 1 shows the analysis of growth parameters of tomato plants. Salinity $(120 \mathrm{mM} \mathrm{NaCl})$ provoked a significant reduction in both leaf dry mass (53\%) and root length (47\%) but root dry mass was not affected. When SNP (NO donor) was added to NaCl-treated plants, significant amelioration was observed. Thus, $100 \mu \mathrm{M}$ and $300 \mu \mathrm{M}$ SNP reduced the loss of leaf dry mass and the diminished of the root length. Again, root dry mass seemed to be not affected.

Table 2 shows the chlorophyll content of tomato plants exposed to $\mathrm{NaCl}(120 \mathrm{mM})$ and the effect of SNP treatment. Salinity caused clear leaf chlorosis symptoms because chlorophyll $a$ and $b$ content was both reduced 52\%. However, when SNP was added the content of chlorophylls was less affected, especially with $300 \mu \mathrm{M}$ SNP $(22 \%)$.

\subsection{Lipid peroxidation and $\mathrm{H}_{2} \mathrm{O}_{2}$ content}

Figure 1 shows the effect of exogenous SNP on lipid oxidation and $\mathrm{H}_{2} \mathrm{O}_{2}$ content in $120 \mathrm{mM} \mathrm{NaCl}$-treated tomato plants. Figure 1 (panels A and B) shows that salinity provoked an increase of $35 \%$ and $37 \%$ of lipid peroxidation in both leaves and roots, respectively. Upon applying $300 \mu \mathrm{M}$ SNP to NaCl- stressed plants, lipid peroxidation was reduced significantly in leaves compared with $\mathrm{NaCl}$ stress only which suggests that this concentration of NO donor reduced the membrane oxidative damage provoked by $\mathrm{NaCl}$. However, this effect was not observed with any concentration of $\mathrm{SNP}$ in roots. Figure 1 (panels $\mathrm{C}$ and $\mathrm{D}$ ) illustrates that $\mathrm{H}_{2} \mathrm{O}_{2}$ content was reduced in both organs of tomato plants treated with $120 \mathrm{mM} \mathrm{NaCl}$. On the other hand, any of the SNP treatments seem to revert this effect on $\mathrm{H}_{2} \mathrm{O}_{2}$ content in any of the analyzed organs.

Table 1. Effect of exogenous SNP (NO donor) on growth parameters in $120 \mathrm{mM} \mathrm{NaCl}$-treated tomato plants. Different letters indicate that differences from control values were statistically significant $(p<0.05)$.

\begin{tabular}{lccc}
\hline $\begin{array}{l}\text { Treatments } \\
\text { Leaf dry mass } \\
(\mathbf{m g})\end{array}$ & $\begin{array}{c}\text { Root dry mass } \\
(\mathbf{m g})\end{array}$ & $\begin{array}{c}\text { Root length } \\
(\mathbf{c m})\end{array}$ \\
\hline $\mathbf{0 ~} \mathbf{m M ~ N a C l}$ & $110 \pm 15$ & $26 \pm 3.2$ & $83.5 \pm 8.3$ \\
\hline $\mathbf{1 2 0} \mathbf{~ m M ~ N a C l} \mathbf{~ m M ~ N a C l}$ & $51 \pm 4.7^{\mathbf{a}}$ & $22 \pm 3.6$ & $44 \pm 4.8^{\mathbf{a}}$ \\
$+\mathbf{1 0 0} \boldsymbol{\mu M ~ S N P}$ & $76 \pm 7^{\mathbf{b}}$ & $25 \pm 3.9$ & $55 \pm 3.9^{\mathbf{b}}$ \\
\hline $\mathbf{1 2 0} \mathbf{~ m M ~ N a C l}$ & & & $63 \pm 6$ \\
$+\mathbf{3 0 0} \boldsymbol{\mu M ~ S N P}$ & $91 \pm 11$ & 252.4 & \\
\hline
\end{tabular}


Table 2. Effect of exogenous SNP (NO donor) on chlorophyll content in leaves of $120 \mathrm{mM} \mathrm{NaCl}$-treated tomato plants. Different letters indicate that differences from control values were statistically significant $(p<0.05)$.

\begin{tabular}{|c|c|c|c|}
\hline Treatments & $\begin{array}{c}\text { Chlorophyll } a \\
\left(\mathrm{mg} \cdot \mathrm{g}^{-1} \mathrm{FW}\right)\end{array}$ & $\begin{array}{c}\text { Chlorophyll } b \\
\left(\mathbf{m g} \cdot \mathbf{g}^{-1} \mathbf{F W}\right)\end{array}$ & $\begin{array}{l}\text { Total chlorophyll } \\
\text { content }\left(\mathrm{mg} \cdot \mathrm{g}^{-1} \mathrm{FW}\right)\end{array}$ \\
\hline $0 \mathrm{mM} \mathrm{NaCl}$ & $1.20 \pm 0.06$ & $0.35 \pm 0.04$ & $1.55 \pm 0.05$ \\
\hline $120 \mathrm{mM} \mathrm{NaCl}$ & $0.58 \pm 0.01^{\mathrm{a}}$ & $0.17 \pm 0.02^{\mathrm{a}}$ & $0.75 \pm 0.06^{\mathrm{a}}$ \\
\hline $\begin{array}{l}120 \mathrm{mM} \mathrm{NaCl} \\
+100 \mu \mathrm{M} \mathrm{SNP}\end{array}$ & $0.68 \pm 0.01$ & $0.19 \pm 0.02$ & $0.87 \pm 0.05$ \\
\hline $\begin{array}{l}120 \mathrm{mM} \mathrm{NaCl} \\
+300 \mu \mathrm{M} \mathrm{SNP}\end{array}$ & $0.94 \pm 0.03^{\mathbf{b}}$ & $0.27 \pm 0.03^{\mathbf{b}}$ & $1.21 \pm 0.08^{\mathrm{b}}$ \\
\hline
\end{tabular}

\subsection{Ascorbate and proline content}

Table 3 shows the effect of exogenous SNP (NO donor) on ascorbate and proline content in leaves and roots of $120 \mathrm{mM} \mathrm{NaCl}$-treated tomato plants. Salinity provoked that the ascorbate content diminished a $60 \%$ and $49 \%$ in leaves and roots, respectively. Upon applying either $100 \mu \mathrm{M}$ or $300 \mu \mathrm{M}$ SNP to $\mathrm{NaCl}$ stressed plants, the diminished ascorbate was less accentuated in both organs. On the other hand, salinity induces proline accumulation in leaves $(22 \%)$ and roots $(29 \%)$. Upon applying $300 \mu \mathrm{M}$ SNP to $\mathrm{NaCl}$ stressed plants, the proline content increased $46 \%$ and $59 \%$ in leaves and roots, respectively.

\subsection{Antioxidant enzyme activities}

Figure 2 represents the effect of exogenous SNP (NO donor) on catalase and superoxide dismutase (SOD) activities in leaves and roots of $120 \mathrm{mM} \mathrm{NaCl}$-treated tomato plants. Figure 2 (panels A and B) shows that catalase activity was not affected in leaves and roots of $120 \mathrm{mM} \mathrm{NaCl}$-treated tomato plants. Upon applying $\mathrm{SNP}$ to $\mathrm{NaCl}$ stressed plants, it was observed a light activity increase in both organs with $100 \mu \mathrm{M}$ SNP but no change was detected with $300 \mu \mathrm{M}$ SNP. On the other hand, Fig. 2 (panels C and D) shows that SOD activity increased in both organs of $120 \mathrm{mM} \mathrm{NaCl}-$ treated tomato plants. Upon applying SNP to $\mathrm{NaCl}$ stressed plants, it was observed a significant increase of SOD activity which was higher with $300 \mu \mathrm{M}$ SNP.

Considering that SOD enzyme has several SOD isoenzymes which can be distinguished by native PAGE, similar experiment was done to determine which SOD isoenzyme(s) is(are) most affected for SNP-treatment. Figure 3 (panels A and B) shows the presence of one $\mathrm{Mn}-\mathrm{SOD}$ and two CuZn-SODs in both organs of control tomato plants. The $\mathrm{CuZn-SODs}$ were designated as I and II by mobility increasing in the gel. When plants were exposed to $120 \mathrm{mM} \mathrm{NaCl}$ treatment, it was observed that MnSOD was apparently not affected but both CuZnSOD (I and II) bands were clearly more intense in both organs . Upon applying SNP to NaCl-stressed plants, the MnSOD of both organs did not shown any significant changes. However, in roots the intensity of the band corresponding to CuZnSOD II increased significantly and appeared also a new CuZn-SOD band designated as III (Figure 3B). 

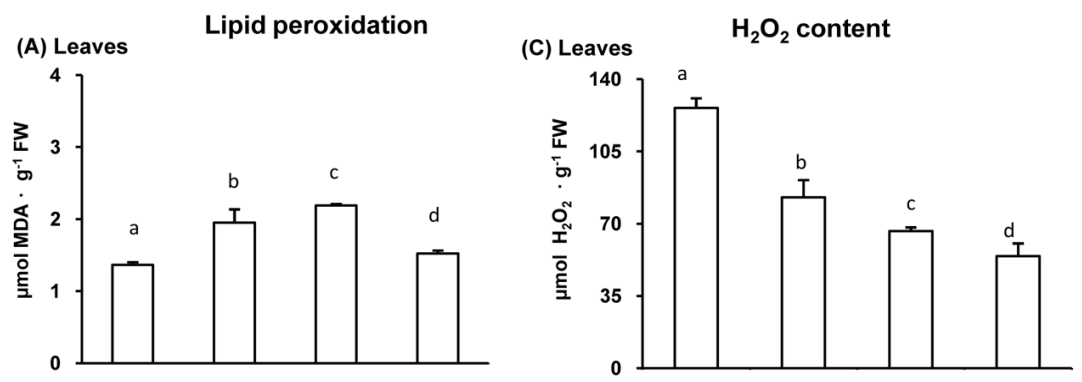

(B) Roots

(D) Roots

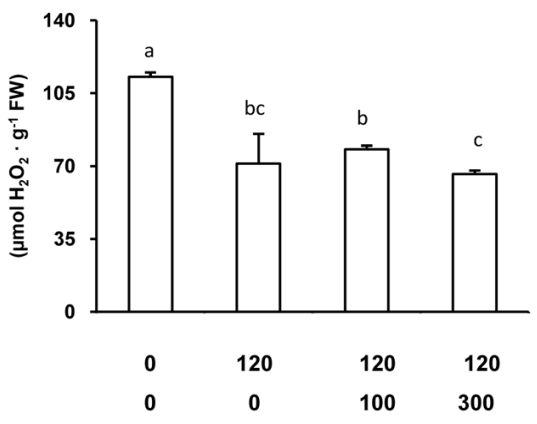

Figure 1. Oxidative stress parameters in leaves and roots of $120 \mathrm{mM} \mathrm{NaCl}$-treated tomato plants supplemented with a NO donor (100 or $300 \mu \mathrm{M} \mathrm{SNP)}$. (A) Lipid peroxidation in leaves. (B) Lipid oxidation in roots. (C) Hydrogen peroxide content in leaves. (D) Hydrogen peroxide in roots. Data are the mean \pm SEM of at least three different experiments. Different letters indicate that differences from control values were statistically significant $(p<0.05)$. FW, fresh weight.

Figure 4 shows the effect of exogenous SNP (NO donor) on APX and GR activities in leaves and roots of $120 \mathrm{mM} \mathrm{NaCl}$-treated tomato plants. Figure 4A illustrates that APX activity was not affected in leaves of $120 \mathrm{mM} \mathrm{NaCl}$-treated tomato plants; however in roots (Figure 4B) the APX activity increased (28\%). Upon applying SNP to $\mathrm{NaCl}$-stressed plants, APX activity in leaves increased with $300 \mu \mathrm{M}$ SNP but in roots the APX activity was enhanced by $45 \%$ and $53 \%$ with both concentration of NO donor. On the other hand, GR activity showed similar behavior in leaves (Figure 4C) and roots (Figure 4D) that the APX activity.

Figure 5A shows that peroxidase (POD) activity had a lightly increase but non-significant in leaves of of $120 \mathrm{mM} \mathrm{NaCl}$-treated tomato plants, however in roots (Figure 5B) the POD activity increased (27\%) clearly. Upon applying SNP to $\mathrm{NaCl}$-stressed plants, POD activity in leaves increased only with 100 $\mu \mathrm{M}$ SNP but in roots the POD activity was clearly enhanced being a $26 \%$ higher with $300 \mu \mathrm{M}$ SNP. 
Table 3. Effect of exogenous SNP (NO donor) on ascorbate and proline content in leaves and roots of $120 \mathrm{mM}$ $\mathrm{NaCl}$-treated tomato plants. Different letters indicate that differences from control values were statistically significant $(p<0.05)$.

\begin{tabular}{|c|c|c|c|c|}
\hline \multirow{2}{*}{ Treatments } & \multicolumn{2}{|c|}{ Ascorbate $\left(\mathrm{mg} \cdot \mathrm{g}^{-1} \mathrm{FW}\right)$} & \multicolumn{2}{|c|}{ Proline $\left(\mu \mathrm{g} \cdot \mathrm{g}^{-1} \mathrm{DW}\right)$} \\
\hline & Leaves & Roots & Leaves & Roots \\
\hline $0 \mathrm{mM} \mathrm{NaCl}$ & $5.1 \pm 0.3$ & $3.7 \pm 0.1$ & $37.9 \pm 2.0$ & $20.2 \pm 2.1$ \\
\hline $120 \mathrm{mM} \mathrm{NaCl}$ & $2.1 \pm 0.3^{\mathrm{a}}$ & $1.9 \pm 0.2^{\mathrm{a}}$ & $49 \pm 5.8^{\mathrm{a}}$ & $28.1 \pm 5.8^{\mathbf{a}}$ \\
\hline $\begin{array}{l}120 \mathrm{mM} \mathrm{NaCl} \\
+100 \mu \mathrm{M} \mathrm{SNP}\end{array}$ & $3.0 \pm 0.2^{\mathbf{b}}$ & $2.1 \pm 0.2^{\mathrm{a}}$ & $52.1 \pm 4.1^{\mathrm{a}}$ & $32.0 \pm 4.1^{\mathrm{a}}$ \\
\hline $\begin{array}{l}120 \mathrm{mM} \mathrm{NaCl} \\
+300 \mu \mathrm{M} \mathrm{SNP}\end{array}$ & $3.1 \pm 0.5^{\mathbf{b}}$ & $2.3 \pm 0.3^{\mathbf{b}}$ & $70.1 \pm 3.2^{\mathbf{c}}$ & $48.8 \pm 3.2^{b}$ \\
\hline
\end{tabular}

3.5. Nitrate reductase (NR) and nitrite reductase $(\mathrm{NiR})$ activities

Figure 6 shows the effect of exogenous SNP (NO donor) on NR and NiR activities in leaves and roots of $120 \mathrm{mM} \mathrm{NaCl}$-treated tomato plants. Figure 6 (panels A and B) shows that NR activity was significantly inhibited in leaves $(39 \%)$ and roots (19\%) of $120 \mathrm{mM} \mathrm{NaCl-treated} \mathrm{tomato} \mathrm{plants.}$ Upon applying SNP to NaCl-stressed plants, it was observed a clear recovery of NR activity in leaves but being even higher in roots. Figure 6 (panels $\mathrm{C}$ and D) shows that NiR activity was not affected in leaves but was inhibited $(30 \%)$ in roots of $120 \mathrm{mM} \mathrm{NaCl}-$ treated tomato plants. Upon applying SNP to $\mathrm{NaCl}-$ stressed plants, it was observed a clear increase of $\mathrm{NiR}$ activity in leaves with both concentration of NO donor but in roots it was not observed any recovery.

\section{Discussion}

Tomato fruit is one of the most consumed vegetables in the world either fresh or processed. However, tomato plants are also sensitive to different adverse environmental conditions including salinity which provoke a significant reduction in crop productivity (Tuteja, 2007). Many research efforts have been done in tomato plants to decipher the multiple mechanisms of response which could help to minimize the harmful salinity effects (Manai et al., 2014; Manaa et al., 2013). Previous data suggest that the exogenous application of NO has the capacity to improve plant tolerance to salinity, metal toxicity, temperature and drought stress in different plant species (Liu et al., 2013; Wu et al., 2011; Esim and Atici, 2014). For example in the calluses of reed (Phragmites communis) under $200 \mathrm{mM} \mathrm{NaCl}$, the addition of sodium nitroprusside, as NO donor, stimulated the expression of the plasma membrane $\mathrm{H}^{+}$- ATPase, indicating that $\mathrm{NO}$ serves as a signal-inducing salt resistance by increasing the $\mathrm{K}^{+}$to $\mathrm{Na}^{+}$ratio (Zhao et al. 2004) and similar behavior was reported for maize (Zhang et al. 2006). Consequently, the goal of this study is to evaluate whether the exogenous $\mathrm{NO}$ application in tomato roots could also alleviate oxidative stress damages provoked for salinity stress in tomato plants. 

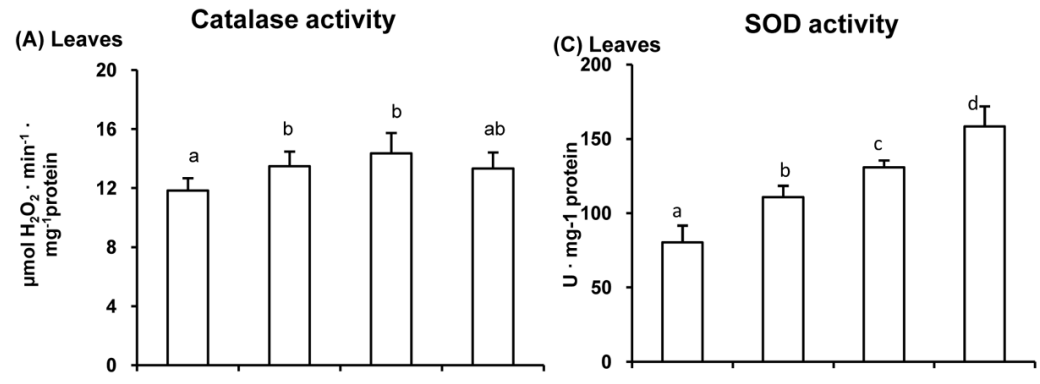

(B) Roots

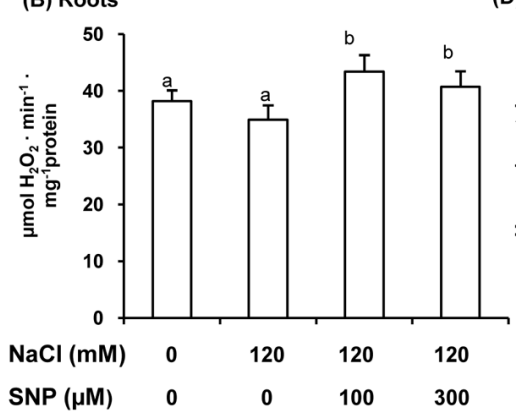

(D) Roots

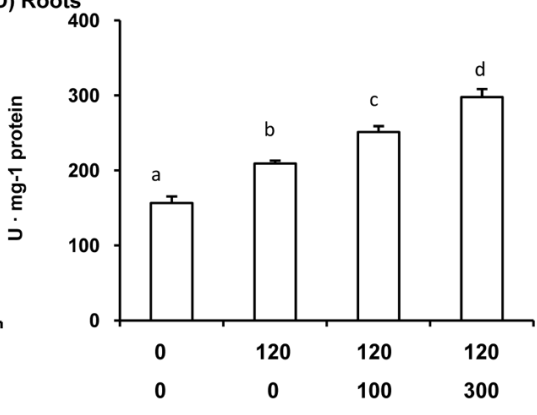

Figure 2. Catalase and superoxide dismutase (SOD) activities in leaves and roots of $120 \mathrm{mM} \mathrm{NaCl}$-treated tomato plants supplemented with a NO donor (100 or $300 \mu \mathrm{M}$ SNP). (A) Catalase activity in leaves. (B) Catalase activity in roots. (C) SOD activity in leaves. (D) SOD activity in roots. Data are the mean $\pm \mathrm{SEM}$ of at least three different experiments. Different letters indicate that differences from control values were statistically significant $(p<0.05)$.

Under our experimental salinity conditions $(120 \mathrm{mM}$ $\mathrm{NaCl}$ ), tomato plants were observed to be affected in relation to the analyzed growth parameters. Moreover, this salinity stress was also accompanied by an oxidative stress as observed by the increase in lipid peroxidation (a well recognized oxidative stress biomarker) and a general stimulation of the antioxidative system such as SOD, APX or POD activities. All these data are in good agreement with previous data reported on tomato plants under salinity stress (Manaa et al., 2013; Manai et al., 2014).
Moreover, similar behavior was observed in the case of both enzymes involved in nitrogen metabolism because both NR and NiR activities were negatively modulated by salt stress (Debouba et al., 2007).

When the NO donor $(100 \mu \mathrm{M}$ or $300 \mu \mathrm{M}$ SNP $)$ was added through the tomato root system, it was observed a clear recover in leaf dray mass, root length and chlorophyll content in leaves, suggesting the beneficial effects of this $\mathrm{NO}$ donor. 
(A) Leaves

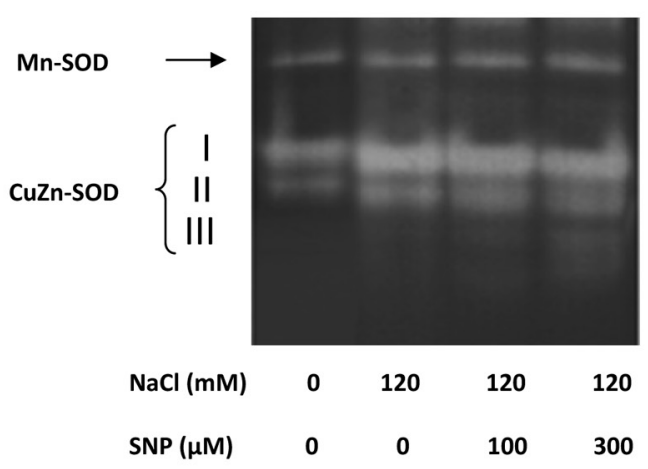

(B) Roots

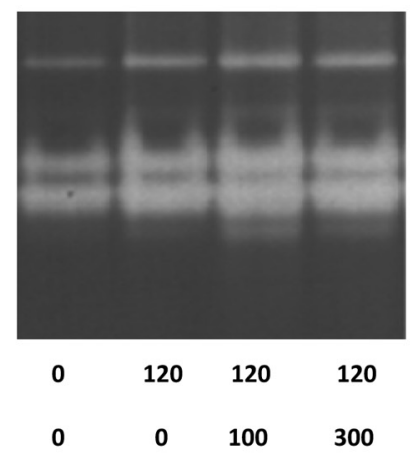

Figure 3. Superoxide dismutase (SOD) isoenzymes activities in native gels in leaves (A) and roots (B) of $120 \mathrm{mM}$ $\mathrm{NaCl}$-treated tomato plants supplemented with a NO donor (100 $\mu \mathrm{M}$ or $300 \mu \mathrm{M} \mathrm{SNP})$.

These data are in also in good agreement with previous reports where NO seems to protect photosynthesis from damage induced by other stresses such as heat stress (Song et al., 2013). Similarly, recent evidence in plants reveals that exogenous NO treatments protect tomato cells from oxidation damage under stress by enhancing the antioxidant enzymes (Nasibi and Kalantari, 2009). The exogenous NO, furthermore, has been reported to alleviate the oxidative damage of salinity to seedling of rice (Wu et al., 2011). NO can induce secondary metabolite accumulation and promote cell death (Bellin et al., 2013). In our experimental system, it was observed a general stimulation of the antioxidative systems. Thus, the application of SNP throughout the roots provokes a general increase in superoxide dismutase, ascorbate peroxidase, glutathione reductase and peroxidase activities in both roots and leaves. A remarkable result was the induction of a new CuZnSOD (III) in roots which suggests that NO donor exerts a regulation at protein and gene level of this antioxidant enzyme. Moreover, these data suggest also the existence of a signaling pathway initiated by NO which effects can be observed in leaves.

In plants NR is a key enzyme of nitrogen assimilation, catalyzing the reduction of nitrate to nitrite, which is further reduced to ammonium by the nitrite reductase $(\mathrm{NiR})$ and then incorporated into amino acids and other nitrogen-derived compounds. In addition, in vitro evidence suggests that NR plays a pivotal role in NO synthesis in plants (Yamasaki and Sakihama, 2000). Thus, NRmediated NO production was induced by various abiotic factors, such as osmotic stress (Nasibi and Kalantari, 2009), and salt stress (Wu et al., 2011). However, it has been also described that NO can regulate NR activity (Du et al., 2008). In our experimental system, it was observed that the exogenous NO application throughout the root system stimulated the NR activity in both roots and leaves which alleviates the negative effect of salinity stress. These data indicate a clear interrelationship between NO and nitrate reductase which allows the nitrogen assimilation during salinity stress. 


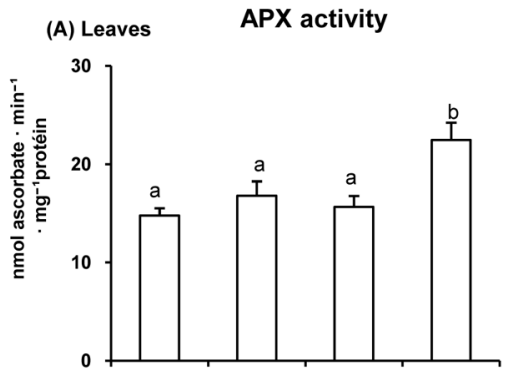

(C) Leaves $\quad$ GR activity
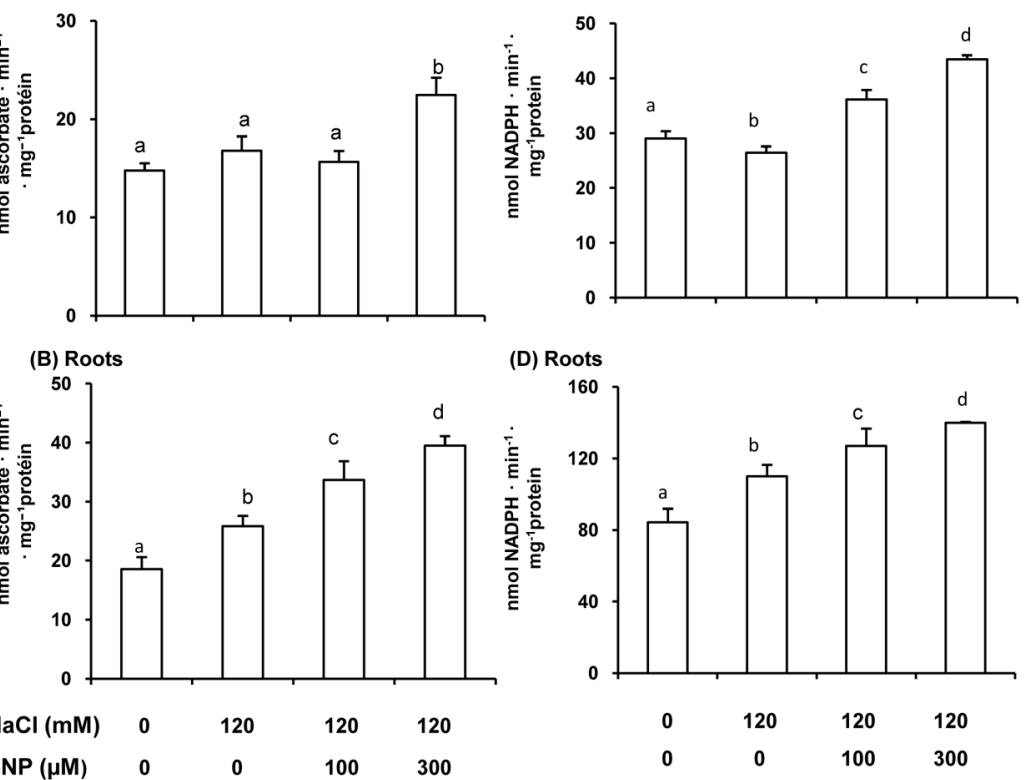

(D) Roots

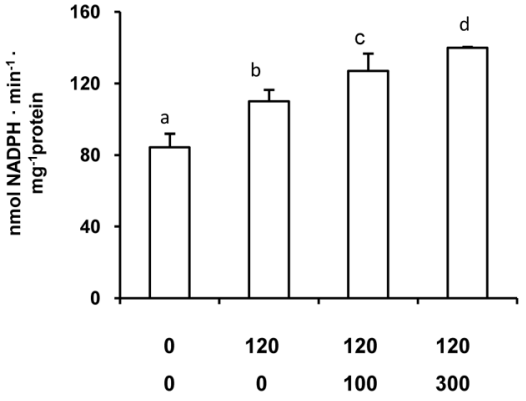

Figure 4. Ascorbate peroxidase (APX) and glutathione reductase (GR) activities in leaves and roots of $120 \mathrm{mM}$ $\mathrm{NaCl}$-treated tomato plants supplemented with a NO donor (100 or $300 \mu \mathrm{M}$ SNP). (A) APX activity in leaves. (B) APX activity in roots. (C) GR activity in leaves. (D) GR activity in roots. Data are the mean $\pm \mathrm{SEM}$ of at least three different experiments. Different letters indicate that differences from control values were statistically significant $(p$ $<0.05)$. 


\section{POD activity}

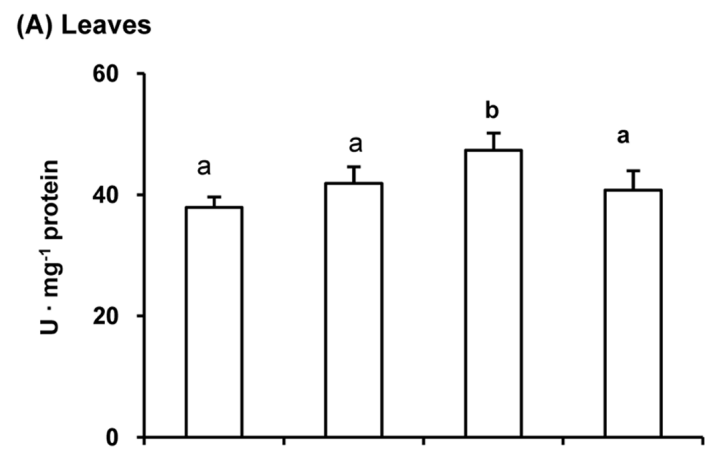

(B) Roots

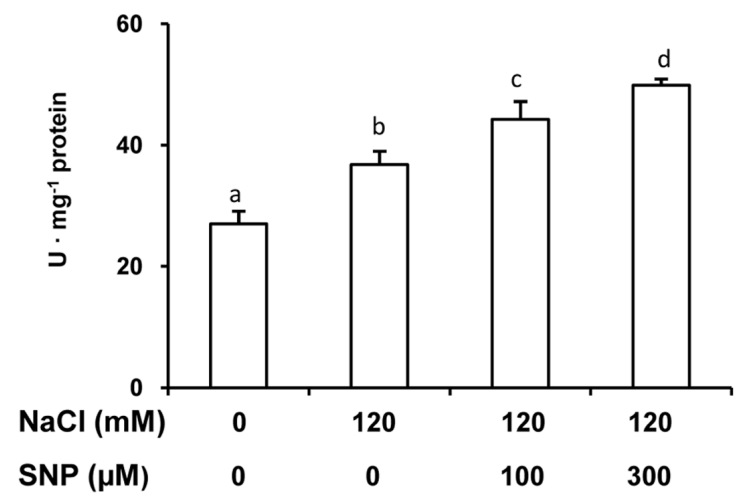

Figure 5. Peroxidase (POD) activity in leaves (A) and roots (B) of $120 \mathrm{mM} \mathrm{NaCl}$-treated tomato plants supplemented with a NO donor (100 or $300 \mu \mathrm{M}$ SNP). Data are the mean \pm SEM of at least three different experiments. Different letters indicate that differences from control values were statistically significant $(p<0.05)$. 


\section{Nitrite reductase}

(A) Leaves

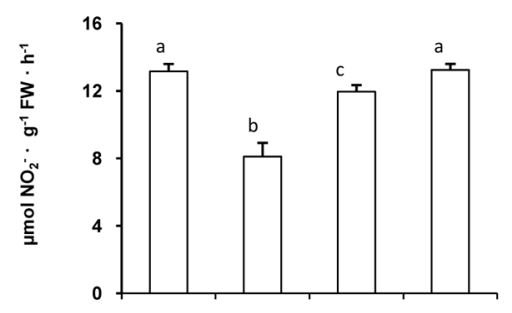

(B) Roots

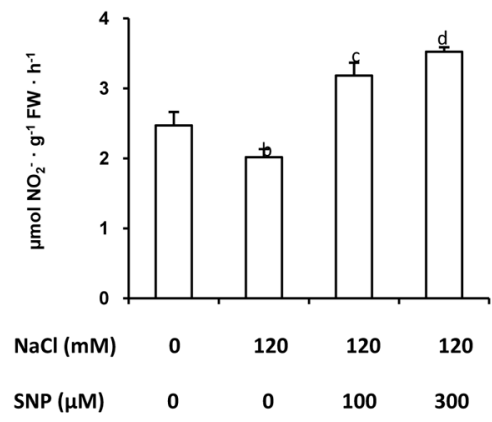

(C) Leaves

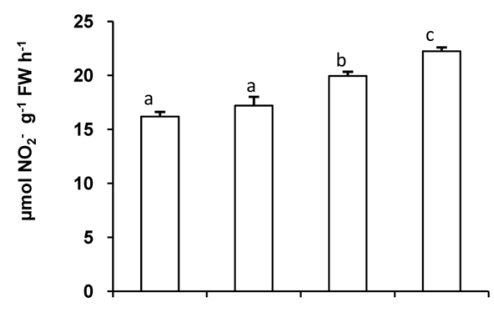

(D) Roots

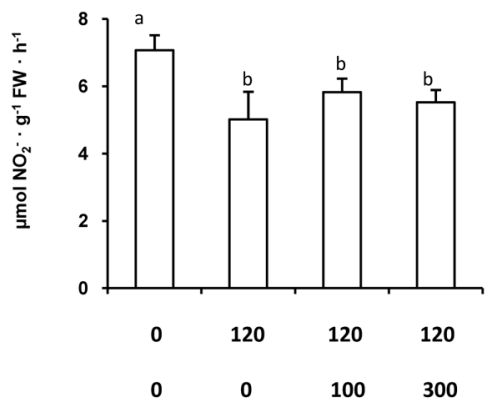

Figure 6. Nitrate reductase (NR) and nitrite reudctase (NiR) activities in leaves and roots of $120 \mathrm{mM} \mathrm{NaCl}$-treated tomato plants supplemented with a NO donor (100 or $300 \mu \mathrm{M}$ SNP). (A) NR activity in leaves. (B) NR activity in roots. (C) NiR activity in leaves. (D) NiR activity in roots. Data are the mean $\pm \mathrm{SEM}$ of at least three different experiments. Different letters indicate that differences from control values were statistically significant $(p<0.05)$.

\section{Conclusion}

Taken together, the results reveal that adding SNP through the roots had significant beneficial effects against $\mathrm{NaCl}$ toxicity in tomato plants, which was reflected in the growth and chlorophyll content in $\mathrm{NaCl}$ exposed plants. Exogenous SNP decreased also $\mathrm{NaCl}$-induced lipid oxidation levels in leaves, and induced the increase of activities of the antioxidant system including SOD, APX, GR and POD in roots and leaves plus the content of ascorbate and proline. In summary, the data suggest that the exogenous application of NO could contribute to ameliorate salinity-induced oxidative stress in tomato plants. Future research in this area under field conditions could contribute to develop a sustainable crop production in salinity contaminated areas. 


\section{Abbreviations}

APX, ascorbate peroxidase; ASC, ascorbate; CAT, catalase; GR, glutathione reductase; $\mathrm{H}_{2} \mathrm{O}_{2}$, hydrogen peroxide; MDA - malondialdehyde; NBT, nitroblue tetrazolium chloride; $\mathrm{NO}$, nitric oxide; nitrite reductase (NiR); nitrate reductase (NR); POD, peroxidase; ROS, reactive oxygen species; SOD, superoxide dismutase; SNP, sodium nitroprusside.

\section{References}

Bates, L.S., Waldren, R.P., Tear, I.D. 1973. Rapid determination of free proline for water-stress studies. Plant Soil. 39, 205-207.

Beauchamp, C.O., Fridovich, I. 1971. Superoxide dismutase: Improved assay and assay applicable to acrylamide gels. Anal. Biochem. 44, 276287.

Begara-Morales, J.C., Sánchez-Calvo, B., Chaki, M., Valderrama, R., Mata-Pérez, C., López-Jaramillo, J., Padilla, M.N., Carreras, A., Corpas, F.J., Barroso, J.B. 2014. Dual regulation of cytosolic ascorbate peroxidase (APX) by tyrosine nitration and S-nitrosylation. J. Exp. Bot. 65, 527-538

Bellin, D., Asai, S., Delledonne, M., Yoshioka, H., 2013. Nitric oxide as a mediator for defense responses. Mol. Plant Microbe Interact. 26, $271-$ 277. doi:10.1094/MPMI-09-12-0214-CR.

Beyer, W.F., Fridovich, Y. 1987. Assaying for superoxide dismutase activity: some large consequences of minor changes in conditions. Analytical Biochemistry. 161, 559-566.

Bradford, M.M. 1976. A rapid and sensitive method for the quantitation of microgram quantities of protein utilizing the principle of protein-dye binding. Analytical Biochemistry. 72, 248-254.
Cavalcanti, F.R., Oliveira, J.T.A., Martins-Miranda, A.S., Viégas, R.A., Silveira, J.A.G. 2004. Superoxide dismutase, catalase and peroxidase activities do not confer Protection against oxidative damage in salt-stressed cowpeas of leaves, Phytol. $163,563-571$

Chen, G.X., Asada, K. 1989. Ascorbate peroxidase in pea leaves: occurrence of two isozymes and the diferences in theirenzymatic and molecular properties. Plant and Cell Physiology. 30, 987998.

Corpas, F.J., Leterrier, M., Valderrama, R., Airaki, M., Chaki, M., Palma, J.M., Barroso, J.B. 2011. Nitric oxide imbalance provokes a nitrosative response in plants under abiotic stress. Plant Sci. 181, 604-11.

Debouba, M., Dghimi, H.M., Suzuki, A., Ghorbel, M.H., Gouia, H. 2007. Changes in growth and activity of enzymes involved in nitrate reduction and ammonium assimilation in tomato seedlings in response to $\mathrm{NaCl}$ Stress. Annals of Botany. 99, 1143-1151.

Du, S., Zhang, Y., Lin, X.Y., Wang, Y., Tang, C.X. 2008. Regulation of nitrate reductase by nitric oxide in Chinese cabbage pakchoi (Brassica chinensis L.). Plant Cell Environ. 31, 195-204.

Esim, N., Atici, O. 2014. Nitric oxide improves chilling tolerance of maize by affecting apoplastic antioxidative enzymes in leaves. Plant Growth Regulation. 72, 29-38.

Foyer, C.H., Noctor, G. 2005. Oxidant and antioxidant signaling in plants: a reevaluation of the concept of oxidative stress in a physiological context. Plant Cell. Environ. 28, 1056-1071.

Gill, S.S., Tuteja, N. 2010. Reactive oxygen species and antioxidant machinery in abiotic stress tolerance in crop plants. Plant Physiol. Biochem. 48, 909-930. 
Hodges, D.M., Andrews, C.J., Johonson, D.A., Hamilton, R.I. 1996. Antioxidant compound responses to chilling stress in differentially sensitive inbred maize 23 lines. Physiol. Plant. 98, 685-692.

Liu, S., Dong, Y.J., Xu, L.L., Kong, J., Bai, X.Y. 2013.. Roles of exogenous nitric oxide in regulating ionic equilibrium and moderating oxidative stress in cotton seedlings during salt stress. Journal of Soil Science and Plant Nutrition. 13, 929-941.

Losada, M, Paneque, A. 1971. Nitrite reductase. Methods in Enzymology. 23, 487-491.

Manaa, A., Mimouni, H., Wasti, S., Gharbi, E., Aschi-Smiti, S., Faurobert, M., Ahmed, H.B. 2013. Comparative proteomic analysis of tomato (Solanum lycopersicum) leaves under salinity stress. Plant OMICS. 6, 268-277.

Manai, J., Gouia, H., Corpas, F.J. 2014. Redox and nitric oxide homeostasis is affected in tomato (Solanum lycopersicum) roots under salinityinduced oxidative stress. Journal Plant Physiology.. 171, 1028-1035.

Nasibi, F., Kalantari, K.M. 2009. Influence of nitric oxide in protection of tomato seedling against oxidative stress induced by osmotic stress. Acta Physiol. Plant. 31, 1037-1044.

Nickel, R.S., Cunningham, B.A. 1969. Improved peroxidase assay method using leuco-2,3' ,6-trichloroindophenol and application to comparative measurements of peroxidase catalysis. Anal Biochem. 27, 292-299.

Rao, M.V., Paliyath, G., Ormrod, D.P. 1996. Ultraviolet-B- and ozone-induced biochemical changes in antioxidant enzymes of Arabidopsis thaliana. Plant Physiology. 110, 125-136.

Robin, P. 1979. Etude de quelques conditions d'extraction de la nitrate réductase des racines et des feuilles de plantules de maïs. Physiologie Végétale. 17, 45-54.

Song, L., Yue, L., Zhao, H., Hou, M. 2013. Protection effect of nitric oxide on photosynthesis in rice under heat stress. Acta Physiologiae Plantarum. 35, 3323-2333.

Tuteja, N. 2007. Mechanisms of high salinity tolerance in plants. Methods Enzymol. 428, 419-38.

Wolff, S. 1994. Ferrous ion oxidation in presence of ferric ion indicator xylenol orange for measurement of hydroperoxides. Methods in Enzymology, 233, 182-189.

Wu, X., Ding, H., Zhu, W., Zhang, H., Zhang, H.J. 2011. Exogenous nitric oxide protects against saltinduced oxidative stress in the leaves from two genotypes of tomato (Lycopersicom esculentum Mill.). Acta Physiol Plant. 23, 304-307.

Yamasaki, H., Sakihama, Y. 2000. Simultaneous production of nitric oxide and peroxynitrite by plant nitrate reductase: in vitro evidence for the NR-dependent formation of active nitrogen species. FEBS Lett. 468, 89-92.

Zhang, Y.Y., Wang, L.L., Liu, Y.L., Zhang, Q., Wei, Q.P., Zhang, W.H. 2006. Nitric oxide enhances salt tolerance in maize seedlings through increasing activities of proton-pump and $\mathrm{Na}^{+} / \mathrm{H}^{+}$antiport in the tonoplast, Planta. 224, 545-555.

Zhao, L., Zhang, F., Guo J., Yang, Y., Li, B., Zhang, L. 2004. Nitric oxide functions as a signal in salt resistance in the calluses from two ecotypes of reed. Plant Physiol. 134, 849-57. 